\title{
Brevundimonas kwangchunensis sp. nov., isolated from an alkaline soil in Korea
}

\author{
Jung-Hoon Yoon, So-Jung Kang, Hyun Woo Oh, Jung-Sook Lee \\ and Tae-Kwang Oh \\ Korea Research Institute of Bioscience and Biotechnology (KRIBB), PO Box 115, Yusong, \\ Taejon, Korea
}

Correspondence

Jung-Hoon Yoon

jhyoon@kribb.re.kr
The genus Brevundimonas was proposed based on the reclassification of two Pseudomonas species as Brevundimonas diminuta and Brevundimonas vesicularis (Segers et al., 1994). Subsequently, several Caulobacter species or subspecies were transferred to the genus Brevundimonas as Brevundimonas alba, B. aurantiaca, B. bacteroides, B. intermedia, B. subvibrioides and B. variabilis (Abraham et al., 1999). Recently, two further Brevundimonas species, Brevundimonas nasdae (Li et al., 2004) and Brevundimonas mediterranea (Fritz et al., 2005), have been described. At the time of writing, there are 10 Brevundimonas species with validly published names. The genus Brevundimonas is characterized chemotaxonomically by having Q-10 as the predominant ubiquinone, $\mathrm{C}_{18: 1}$ and $\mathrm{C}_{16: 0}$ as the major fatty acids and DNA G $+\mathrm{C}$ contents of 65-68 mol\% (Segers et al., 1994; Abraham et al., 1999; Li et al., 2004; Fritz et al., 2005).

Published online ahead of print on 4 November 2005 as DOI 10.1099/ ijs.0.63784-0.

The GenBank/EMBL/DDBJ accession numbers for the 16S rRNA gene sequences of strains KSL-102 ${ }^{\top}$ and KSL-110 are AY971368 and AY971369.

Tables detailing Biolog assimilation data and the cellular fatty acid compositions of Brevundimonas kwangchunensis sp. nov. and other Brevundimonas species are available as supplementary material in IJSEM Online.
Phylogenetic analyses based on 16S rRNA gene sequences show that the genus falls within the Alphaproteobacteria (Abraham et al., 1999; Anzai et al., 2000; Li et al., 2004; Fritz et al., 2005). In this study, we report on the taxonomic characterization of two Brevundimonas-like bacterial strains, KSL- $102^{\mathrm{T}}$ and KSL-110, which were isolated from an alkaline soil (approximate pH 9.0-10·0) in Korea.

Strains KSL-102 ${ }^{\mathrm{T}}$ and KSL-110 were isolated by the standard dilution-plating technique at $30{ }^{\circ} \mathrm{C}$ on $10 \times$ diluted nutrient agar (NA; Difco) with $\mathrm{pH}$ adjusted to $10 \cdot 0$. The type strains of 10 Brevundimonas species were used as reference strains. B. diminuta LMG $2089^{\mathrm{T}}$, B. vesicularis $\mathrm{LMG} 2350^{\mathrm{T}}$, B. alba LMG $18360^{\mathrm{T}}$, B. aurantiaca LMG $18359^{\mathrm{T}}$, B. bacteroides LMG $15096^{\mathrm{T}}$, B. intermedia LMG $18361^{\mathrm{T}}$, B. subvibrioides LMG $14903^{\mathrm{T}}$, B. variabilis LMG $18362^{\mathrm{T}}$ and B. mediterranea LMG $21911^{\mathrm{T}}$ were obtained from the Laboratorium voor Microbiologie Universiteit Gent (LMG), Gent, Belgium. B. nasdae DSM $14572^{\mathrm{T}}$ was obtained from the Deutsche Sammlung von Mikroorganismen und Zellkulturen (DSMZ), Braunschweig, Germany. To investigate their morphological and physiological characteristics, strains KSL- $102^{\mathrm{T}}$ and KSL110 were routinely cultivated at $30{ }^{\circ} \mathrm{C}$ on trypticase soy agar (TSA; Difco). Cell morphology was examined by light microscopy (Nikon E600) and transmission electron microscopy. The presence of flagella was examined by 
transmission electron microscopy using cells from exponentially growing cultures. The Gram reaction was determined using the bioMérieux Gram stain kit according to the manufacturer's instructions. Growth at various temperatures $\left(4-40{ }^{\circ} \mathrm{C}\right)$ was measured on TSA. Growth at various $\mathrm{NaCl}$ concentrations was investigated in trypticase soy broth (TSB; Difco) and in TSB lacking $\mathrm{NaCl}$. The $\mathrm{pH}$ range for growth was determined in nutrient broth (NB; Difco) that was adjusted to various $\mathrm{pH}$ values (initial $\mathrm{pH} 4 \cdot 5-11 \cdot 5$ at intervals of $0.5 \mathrm{pH}$ units). The $\mathrm{pH}$ was adjusted prior to sterilization to various levels by the addition of $\mathrm{HCl}$ or $\mathrm{Na}_{2} \mathrm{CO}_{3}$ (below $\mathrm{pH} 10 \cdot 5$ ) and $\mathrm{KOH}$ (above $\mathrm{pH} 10 \cdot 5$ ). Growth under anaerobic conditions was determined after incubation in an anaerobic chamber on TSA and on TSA supplemented with nitrate, both of which had been prepared anaerobically using nitrogen. Catalase and oxidase activities and hydrolysis of casein, gelatin, hypoxanthine, starch, Tweens 20, 40, 60 and 80, tyrosine, urea and xanthine were determined as described by Cowan \& Steel (1965). Hydrolysis of aesculin and nitrate reduction were studied as described by Lanyi (1987). Oxidation of various substrates was determined by using the Biolog GN2 MicroPlate assay as recommended by the manufacturer. Sensitivity to antibiotics was tested on TSA plates using discs containing the following antibiotics: polymyxin B (100 U), streptomycin $(50 \mu \mathrm{g})$, penicillin $\mathrm{G}(20 \mathrm{U})$, chloramphenicol $(100 \mu \mathrm{g})$, ampicillin $(10 \mu \mathrm{g})$, cephalothin $(30 \mu \mathrm{g})$, gentamicin $(30 \mu \mathrm{g})$, novobiocin $(5 \mu \mathrm{g})$, tetracycline $(30 \mu \mathrm{g})$, kanamycin $(30 \mu \mathrm{g})$, lincomycin $(15 \mu \mathrm{g})$ and oleandomycin $(15 \mu \mathrm{g})$. Enzyme activity was determined by using the API ZYM system (bioMérieux). Other physiological and biochemical tests were performed with the API 20E system (bioMérieux). Morphological, cultural, physiological and biochemical characteristics of strains KSL-102 ${ }^{\mathrm{T}}$ and KSL-110 are given in the species description (see below) or are shown in Table 1 and Supplementary Table S1 in IJSEM Online.

Cell biomass for DNA extraction and for isoprenoid quinone analysis was obtained from cultivation in TSB at $30^{\circ} \mathrm{C}$. Cell mass of the type strains of 10 Brevundimonas species was obtained by cultivation in recommended liquid media at 25 or $30^{\circ} \mathrm{C}$. Chromosomal DNA was isolated and purified according to the method described by Yoon et al. (1996), with the exception that RNase T1 was used in combination with RNase A to minimize contamination with RNA. The $16 \mathrm{~S}$ rRNA gene was amplified by PCR using two universal primers as described previously (Yoon et al., 1998). Sequencing of the amplified 16S rRNA gene and phylogenetic analysis were performed as described by Yoon et al. (2003). The 16S rRNA gene sequences of strains KSL-102 ${ }^{\mathrm{T}}$ and KSL-110 determined in this study comprised $1416 \mathrm{nt}$, representing approximately $96 \%$ of the Escherichia coli $16 \mathrm{~S}$ rRNA gene sequence. The $16 \mathrm{~S}$ rRNA gene sequences of the two strains were $99 \cdot 8 \%$ similar (three nucleotide differences). Comparative 16S rRNA gene sequence analyses showed that strains KSL- $102^{\mathrm{T}}$ and KSL-110 are phylogenetically most closely affiliated to the genus Brevundimonas (Fig. 1). The relationship between the cluster comprising the two strains and Brevundimonas species and the cluster comprising Caulobacter species was supported by a relatively high bootstrap resampling value $(78 \cdot 8 \%$; Fig. 1$)$. The $16 \mathrm{~S}$ rRNA gene sequences of strains KSL- $102^{\mathrm{T}}$ and KSL-110 exhibited similarity values of $96 \cdot 3-98 \cdot 4 \%$ with respect to those of the type strains of recognized Brevundimonas species. Sequence similarities to all other species included in the phylogenetic analysis were less than $95 \cdot 2 \%$ (Fig. 1).

Isoprenoid quinones were extracted according to the method of Komagata \& Suzuki (1987) and analysed using reversedphase HPLC and a YMC ODS-A $(250 \times 4 \cdot 6 \mathrm{~mm})$ column. For fatty acid methyl ester analysis, cell mass of strains KSL$102^{\mathrm{T}}$ and KSL-110 $\left(30^{\circ} \mathrm{C}\right)$ and B. diminuta LMG $2089^{\mathrm{T}}$ and B. vesicularis LMG $2350^{\mathrm{T}}\left(25^{\circ} \mathrm{C}\right)$ was harvested from agar plates after incubation for 3 days on TSA and for 7 days on LMG medium no. 221, and cell mass of B. alba LMG $18360^{\mathrm{T}}$, B. aurantiaca LMG $18359^{\mathrm{T}}$, B. bacteroides LMG $15096^{\mathrm{T}}$, B. subvibrioides LMG $14903^{\mathrm{T}}$ and $B$. variabilis $\mathrm{LMG} 18362^{\mathrm{T}}$ was harvested from agar plates after incubation for 7 days on LMG medium no. 221 at $30^{\circ} \mathrm{C}$. The fatty acid methyl esters were extracted and prepared according to the standard protocol of the MIDI/Hewlett Packard Microbial Identification System (Sasser, 1990). The DNA G + C content was determined by the method of Tamaoka \& Komagata (1984) with a modification that DNA was hydrolysed and the resultant nucleotides were analysed by reversed-phase HPLC. Chemotaxonomic data support the result of monothetic phylogenetic classification of strains KSL- $102^{\mathrm{T}}$ and KSL-110 as members of the genus Brevundimonas. Strains KSL- $102^{\mathrm{T}}$ and KSL-110 contained ubiquinone with 10 isoprene units $(\mathrm{Q}-10)$ as the predominant respiratory lipoquinone. This predominant ubiquinone type was the same as those of Brevundimonas species (Segers et al., 1994; Abraham et al., 1999; Li et al., 2004; Fritz et al., 2005). The fatty acid profiles of strains KSL- $102^{\mathrm{T}}$ and KSL-110 were characterized by a common core of straight-chain, unsaturated, hydroxy fatty acids and 11 -methyl $\mathrm{C}_{18: 1} \omega 7 \mathrm{c}$ in similar amounts when the two strains were cultivated in identical medium of both TSA and LMG medium no. 221 (Supplementary Table S2 in IJSEM Online). The major fatty acids were $\mathrm{C}_{18: 1} \omega 7 \mathrm{c}$ and $\mathrm{C}_{16: 0}$ on TSA and $\mathrm{C}_{18: 1} \omega 7 c, 11$-methyl $\mathrm{C}_{18: 1} \omega 7 c$ and $\mathrm{C}_{16: 0}$ on LMG medium no. 221. The proportion of 11-methyl $\mathrm{C}_{18: 1} \omega 7 \mathrm{c}$ increased and the proportion of $\mathrm{C}_{18: 1} \omega \mathrm{c} c \mathrm{decreased}$ when they were grown on LMG medium no. 221. The fatty acid profiles of the two strains were similar to those of Brevundimonas species analysed here (Supplementary Table S2 in IJSEM Online) and determined previously (Abraham et al., 1999; Li et al., 2004; Fritz et al., 2005). Cyclo- $\mathrm{C}_{19: 0} \omega 8 c$, which was detected in some Brevundimonas species, including $B$. diminuta, B. nasdae and B. alba, was not found in strains KSL- $102^{\mathrm{T}}$ and KSL- 110 . The DNA G + C contents of strains KSL- $102^{\mathrm{T}}$ and KSL-110 were 68.7 and $68.4 \mathrm{~mol} \%$, respectively, higher than those of recognized Brevundimonas species (Table 1).

DNA-DNA hybridization was performed fluorometrically according to the method of Ezaki et al. (1989) using 
Table 1. Differential phenotypic characteristics of Brevundimonas kwangchunensis sp. nov. and other Brevundimonas species

Species: 1, B. kwangchunensis; 2, B. diminuta (data from Palleroni, 1984; Segers et al., 1994; Li et al., 2004); 3, B. vesicularis (Palleroni, 1984; Segers et al., 1994; Li et al., 2004); 4, B. alba (Poindexter, 1964); 5, B. aurantiaca (Poindexter, 1964; Li et al., 2004); 6, B. bacteroides (Poindexter, 1964); 7, B. intermedia (Poindexter, 1964; Li et al., 2004); 8, B. subvibrioides (Poindexter, 1964); 9, B. variabilis (Poindexter, 1964); 10, B. nasdae (Li et al., 2004); 11, B. mediterranea (Fritz et al., 2005). +, Positive; -, negative; ND, not determined; W, weakly positive; V, variable; data in parentheses are for the type strain. Cells of all species are Gram-negative and rod-shaped.

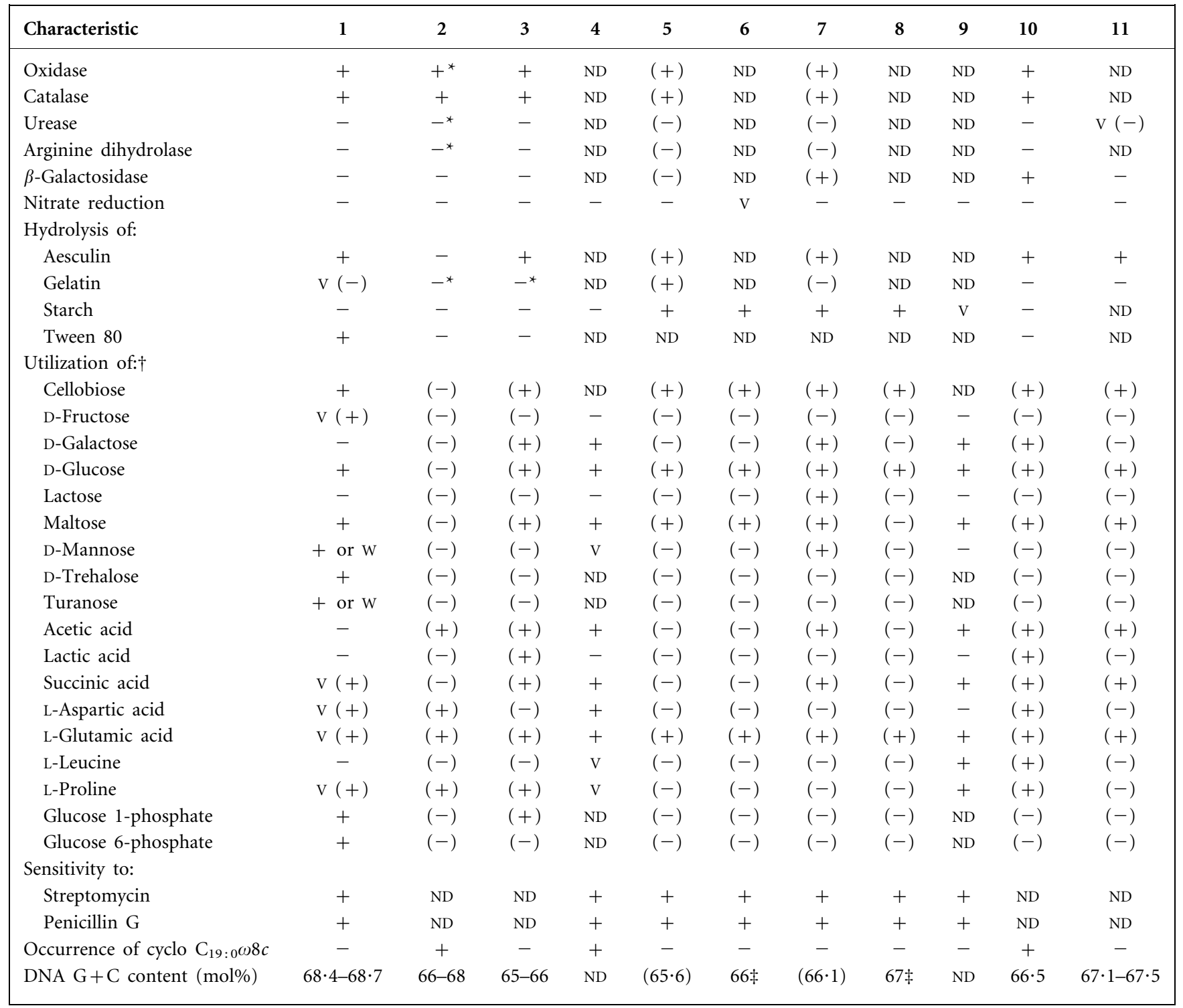

${ }^{*}$ Data taken from Palleroni (1984) and Segers et al. (1994); different results for the type strains were reported by Li et al. (2004). $\dagger$ Data from Biolog GN2 MicroPlate assay in this study; data for B. alba and B. variabilis were taken from Poindexter (1964).

¥Reported for one isolate by Poindexter (1989).

photobiotin-labelled DNA probes and microdilution wells at $60^{\circ} \mathrm{C}$. Hybridization was performed with five replications for each sample. The highest and lowest values obtained for each sample were excluded, and the means of the remaining three values were quoted as DNA-DNA relatedness values. Mean DNA-DNA relatedness between strains KSL-102 ${ }^{\mathrm{T}}$ and KSL-110 was $85 \%$ when their DNAs were used individually as labelled DNA probes for cross-hybridization. This value indicates that the two strains are members of the same genomic species (Wayne et al., 1987). Strains KSL$102^{\mathrm{T}}$ and KSL-110 were similar to each other with regard to most phenotypic properties. However, the two strains differed in the oxidation of some substrates, indicating that they may represent ecotypes of the same species, as suggested by Konstantinidis \& Tiedje (2005). The two strains exhibited levels of DNA-DNA relatedness of 8-21\% 


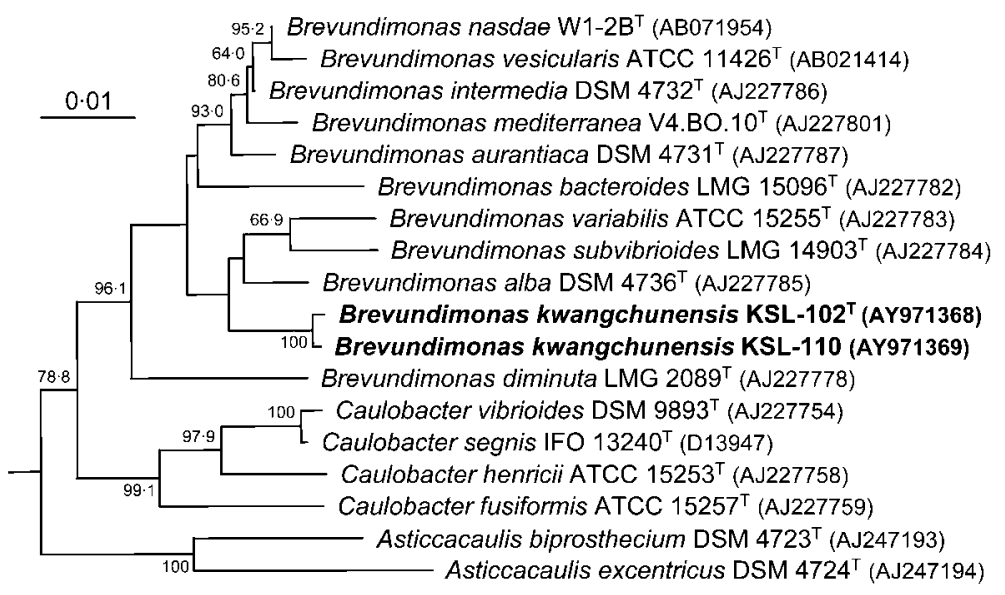

Fig. 1. Neighbour-joining phylogenetic tree based on 16S rRNA gene sequences showing the positions of Brevundimonas kwangchunensis strains $\mathrm{KSL}-102^{\top}$ and $\mathrm{KSL}-110$, Brevundimonas species and some other related taxa. Bootstrap values (expressed as percentages of 1000 replications) $>50 \%$ are shown at branch points. Rhodospirillum rubrum ATCC $11170^{\top}$ was used as an outgroup (not shown). Bar, 0.01 substitutions per nucleotide position.

to the type strains of the 10 recognized Brevundimonas species.

The phylogenetic distinctiveness and DNA-DNA relatedness data were sufficient to categorize strains KSL- $102^{\mathrm{T}}$ and KSL-110 as members of a species that is distinct from all recognized Brevundimonas species (Wayne et al., 1987; Stackebrandt \& Goebel, 1994). There were some differences between the two strains and Brevundimonas species in their phenotypic characteristics (Table 1). Therefore, on the basis of the data presented, strains KSL- $102^{\mathrm{T}}$ and KSL-110 should be classified in the genus Brevundimonas as members of a novel species, for which the name Brevundimonas kwangchunensis sp. nov. is proposed.

\section{Description of Brevundimonas kwangchunensis sp. nov.}

Brevundimonas kwangchunensis (kwang.chun.en'sis. N.L. fem. adj. kwangchunensis of Kwangchun, from where the first strains were isolated).

Cells are Gram-negative, aerobic rods $(0 \cdot 4-0 \cdot 6 \mu \mathrm{m} \times 1 \cdot 0-$ $3 \cdot 0 \mu \mathrm{m})$, motile by means of a single polar flagellum. Colonies on TSA are circular, smooth, glistening, slightly convex, greyish yellow in colour and $1 \cdot 5-2 \cdot 0 \mathrm{~mm}$ in diameter after 3 days incubation at $30{ }^{\circ} \mathrm{C}$. Colonies on LMG medium no. 221 are circular, smooth, glistening, slightly convex, yellowish white in colour and $1 \cdot 0-2 \cdot 0 \mathrm{~mm}$ in diameter after 3 days incubation at $30^{\circ} \mathrm{C}$. Optimal temperature for growth is $30^{\circ} \mathrm{C}$. Growth occurs at 10 and $36^{\circ} \mathrm{C}$, but not at 4 or $37^{\circ} \mathrm{C}$. Optimal pH for growth is between $7 \cdot 0$ and $8 \cdot 0$; growth occurs at $\mathrm{pH} 6.0$ and $9 \cdot 5$, but not at $\mathrm{pH} 5.5$ or 10.0 . Growth occurs in the presence of $0-2 \%(w / v) ~ N a C l$; optimal growth occurs without $\mathrm{NaCl}$. Anaerobic growth does not occur on TSA or on TSA supplemented with nitrate. Casein and Tweens 20, 40, 60 and 80 are hydrolysed. Hypoxanthine, xanthine and tyrosine are not hydrolysed. $\mathrm{H}_{2} \mathrm{~S}$ and indole are not produced. Lysine decarboxylase, ornithine decarboxylase and tryptophan deaminase are absent. In assays with the API ZYM system, alkaline phosphatase, esterase (C4), esterase lipase (C8), leucine arylamidase, trypsin, acid phosphatase and naphthol-AS-BI-phosphohydrolase are present, but lipase (C14), valine arylamidase, cystine arylamidase, $\alpha$-chymotrypsin, $\alpha$-galactosidase, $\beta$-glucuronidase, $\alpha$-glucosidase, $\beta$-glucosidase, $N$-acetyl- $\beta$-glucosaminidase, $\alpha$-mannosidase and $\alpha$-fucosidase are absent. Sensitive to chloramphenicol, cephalothin, novobiocin, tetracycline and kanamycin and weakly sensitive to polymyxin B, but resistant to ampicillin, gentamicin, lincomycin and oleandomycin. The predominant ubiquinone is Q-10. The major fatty acids are $\mathrm{C}_{18: 1} \omega 7 c$ and $\mathrm{C}_{16: 0}$ on TSA; 11methyl $\mathrm{C}_{18: 1} \omega 7 c$ is a major component when cultivated on LMG medium no. 221. The DNA G+C content is 68.4-68.7 mol\% (68.7 mol\% for type strain) (determined by HPLC). Other phenotypic characteristics are given in Table 1 and Supplementary Tables S1 and S2 in IJSEM Online.

The type strain, KSL-102 $2^{\mathrm{T}} \quad\left(=\mathrm{KCTC} \quad 12380^{\mathrm{T}}=\mathrm{DSM}\right.$ $17033^{\mathrm{T}}$ ), was isolated from an alkaline soil in Kwangchun, Korea. Strain KSL-110 is a reference strain.

\section{Acknowledgements}

This work was supported by the 21C Frontier programme of Microbial Genomics and Applications (grant MG02-0401-001-1-0-0) from the Ministry of Science and Technology (MOST) of the Republic of Korea.

\section{References}

Abraham, W.-R., Strömpl, C., Meyer, H. \& 8 other authors (1999). Phylogeny and polyphasic taxonomy of Caulobacter species. Proposal of Maricaulis gen. nov. with Maricaulis maris (Poindexter) comb. nov. as the type species, and emended description of the genera Brevundimonas and Caulobacter. Int J Syst Bacteriol 49, 1053-1073.

Anzai, Y., Kim, H., Park, J.-Y., Wakabayashi, H. \& Oyaizu, H. (2000). Phylogenetic affiliation of the pseudomonads based on 16S rRNA sequence. Int J Syst Evol Microbiol 50, 1563-1589.

Cowan, S. T. \& Steel, K. J. (1965). Manual for the Identification of Medical Bacteria. London: Cambridge University Press. 
Ezaki, T., Hashimoto, Y. \& Yabuuchi, E. (1989). Fluorometric deoxyribonucleic acid-deoxyribonucleic acid hybridization in microdilution wells as an alternative to membrane filter hybridization in which radioisotopes are used to determine genetic relatedness among bacterial strains. Int J Syst Bacteriol 39, 224-229.

Fritz, I., Strömpl, C., Nikitin, D. I., Lysenko, A. M. \& Abraham, W.-R. (2005). Brevundimonas mediterranea sp. nov., a non-stalked species from the Mediterranean Sea. Int J Syst Evol Microbiol 55, 479-486.

Komagata, K. \& Suzuki, K. (1987). Lipids and cell-wall analysis in bacterial systematics. Methods Microbiol 19, 161-203.

Konstantinidis, K. T. \& Tiedje, J. M. (2005). Genomic insights that advance the species definition for prokaryotes. Proc Natl Acad Sci U S A 102, 2567-2572.

Lanyi, B. (1987). Classical and rapid identification methods for medically important bacteria. Methods Microbiol 19, 1-67.

Li, Y., Kawamura, Y., Fujiwara, N., Naka, T., Liu, H., Huang, X., Kobayashi, K. \& Ezaki, T. (2004). Sphingomonas yabuuchiae sp. nov. and Brevundimonas nasdae sp. nov., isolated from the Russian space laboratory Mir. Int J Syst Evol Microbiol 54, 819-825.

Palleroni, N. J. (1984). Genus Pseudomonas Migula 1894. In Bergey's Manual of Systematic Bacteriology, vol. 1, pp. 141-199. Edited by N. R. Krieg \& J. G. Holt. Baltimore: Williams \& Wilkins.

Poindexter, J. S. (1964). Biological properties and classification of the Caulobacter group. Bacteriol Rev 28, 231-295.

Poindexter, J. S. (1989). Genus Caulobacter Henrici and Johnson 1935. In Bergey's Manual of Systematic Bacteriology, vol. 3, pp. 1924-1939. Edited by J. T. Staley, M. P. Bryant, N. Pfennig \& J. G. Holt. Baltimore: Williams \& Wilkins.
Sasser, M. (1990). Identification of bacteria by gas chromatography of cellular fatty acid. Technical Note no. 101. Newark, DE: MIDI Inc.

Segers, P., Vancanneyt, M., Pot, B., Torck, U., Hoste, B., Dewettinck, D., Falsen, E., Kersters, K. \& De Vos, P. (1994). Classification of Pseudomonas diminuta Leifson and Hugh 1954 and Pseudomonas vesicularis Büsing, Döll, and Freytag 1953 in Brevundimonas gen. nov. as Brevundimonas diminuta comb. nov. and Brevundimonas vesicularis comb. nov., respectively. Int J Syst Bacteriol 44, 499-510.

Stackebrandt, E. \& Goebel, B. M. (1994). Taxonomic note: a place for DNA-DNA reassociation and $16 \mathrm{~S}$ rRNA sequence analysis in the present species definition in bacteriology. Int J Syst Bacteriol 44, 846-849.

Tamaoka, J. \& Komagata, K. (1984). Determination of DNA base composition by reverse-phase high-performance liquid chromatography. FEMS Microbiol Lett 25, 125-128.

Wayne, L. G., Brenner, D. J., Colwell, R. R. \& 9 other authors (1987). Report of the ad hoc committee on reconciliation of approaches to bacterial systematics. Int J Syst Bacteriol 37, 463-464.

Yoon, J.-H., Kim, H., Kim, S.-B., Kim, H.-J., Kim, W. Y., Lee, S. T., Goodfellow, M. \& Park, Y.-H. (1996). Identification of Saccharomonospora strains by the use of genomic DNA fragments and rRNA gene probes. Int J Syst Bacteriol 46, 502-505.

Yoon, J.-H., Lee, S. T. \& Park, Y.-H. (1998). Inter- and intraspecific phylogenetic analysis of the genus Nocardioides and related taxa based on 16S rRNA gene sequences. Int J Syst Bacteriol 48, 187-194.

Yoon, J.-H., Kang, K. H. \& Park, Y.-H. (2003). Psychrobacter jeotgali sp. nov., isolated from jeotgal, a traditional Korean fermented seafood. Int J Syst Evol Microbiol 53, 449-454. 